\title{
EFFECT OF POMEGRANATE PEEL ADDITION TO THE DIET ENRICHED WITH LINSEED OIL ON PERFORMANCE, LIPID TRAITS IN THE MEAT, BLOOD LIPID PROFILE AND ANTIOXIDANT PROPERTY OF RABBITS UNDER SUMMER CONDITIONS
}

\author{
H.S. Zeweil; M.H. Ahmed; S.M. Zahran; Yassmine M.El-Gindy and E.A.S. Abdulgader \\ Department of Animal and Fish Production, Faculty of Agriculture (Saba Basha), Alexandria University, \\ Alexandria, Egypt.
}

(Received $17 / 10 / 2016$, Accepted $15 / 12 / 2016)$

\section{SUMMARY}

$\mathrm{T}$ he present work aimed to investigate the growth performance, meat omega-3 (n-3) and omega 6 (n-6) fatty acids, immunological responses, lipid peroxide and the antioxidative status resulting from supplemented linseed oil diets of growing V-line rabbits with two levels of pomegranate peel (POM) during summer season from June to August. Forty-eight growing V-line rabbits of both sexes, 7 weeks old, with initial weight of $982.75 \pm 15.85 \mathrm{~g}$ were used in the present experiment. Rabbits were randomly distributed to four groups of 12 rabbits each. Each group was further sub-divided into 4 replicates of 3 rabbits. Group 1 fed a pelleted basal diet with standard components and served as control group, group 2 fed a pelleted diet with $2 \%$ linseed oil, group 3 fed a pelleted diet containing $2 \%$ linseed oil with $0.75 \%$ POM, group 4 fed a pelleted diet containing $2 \%$ linseed oil with $1.5 \%$ POM. The obtained results showed that the different treatments had insignificant effect on final body weight and daily body weight gain, however, significant $(\mathrm{P} \leq 0.05)$ decrease in feed intake and significant $(\mathrm{P} \leq 0.05)$ improvement in feed conversion were recorded in comparison with the control. Results for pre-slaughter weight, percentage of hot carcass and liver were insignificantly affected by different treatments in comparison with control. The different treatments showed significant decrease in the abdominal fat and the muscle total cholesterol in comparison with the control group. The $\mathrm{n}-3$ fatty acids were significantly $(\mathrm{P} \leq 0.05)$ increased by feeding linseed oil, linseed oil plus pomegranate peel, while the $\mathrm{n}-6$ fatty acids were decreased significantly by feeding linseed oil and linseed oil plus pomegranate peel in comparison with control. Hematological parameters and antibody titers against sheep red blood cells (SRBCs) were insignificantly affected by different treatments. While, specific IgG was significantly improved in all experimental groups compared with control. Serum total lipids, low density lipoprotein and malondialdehyde (MDA) were significantly $(P \leq 0.05)$ decreased due to different experimental diets in comparison with the control group. Total cholesterol was decreased but triglycerides were increased in animals received linseed oil in their diet in comparison with control. High density lipoprotein concentration, HDL/LDL ratio and total antioxidant capacity were significantly $(\mathrm{P} \leq 0.05)$ increased by different experimental treatments as compared with the control group, with one exception that TAC was insignificantly increased than in control by receiving linseed oil in the diet. It is concluded that dietary supplementation of linseed oil plus POM in growing rabbit's diets had a beneficial effect on the composition of the meat lipid fraction by increasing the concentration of $n-3$ fatty acids and improving the feed conversion, blood serum lipid profile and antioxidant status.

Keywords: Rabbits, heat stress, linseed oil, pomegranate peel, growth performance and immunological response.

\section{INTRODUCTION}

Stress is a reflex reaction of animals in harsh environments and causes unfavorable consequences ranges from discomfort to death. Climate change is one of the major threats for survival of various species, ecosystems and the sustainability of animal production systems across the world (Das et al., 2016), especially in tropical and sub-tropical areas like Egypt. Exposure growing rabbits to > 86THI (temperature-humidity index) units as severe heat stress during summer adversely affects their productive traits and reduces the resistance to diseases (Marai et al., 2002). Exposing rabbits to heat stress reduces their growth rate, average daily gain and feed efficiency (Villalobos et al., 2008) leading to major production losses. High environmental temperature not only has adverse effects on rabbits' performance but also cause an increase in oxidative stress (Lee, 2002) which result to increase in reactive oxygen species in different cells and tissues of 
stressed animals that have negative impacts on normal physiology and body metabolism (Das et al., 2016), with impede disease resistance and impairs antioxidant status (Sabin et al., 2001). Several studies confirmed many positive effects of dietary polyunsaturated fatty acid (n-PUFAs) including lipid Peroxidation, antioxidative properties, immune response and bone strength. Studies elucidated that a moderate intake of n-3 polyunsaturated fatty acids (PUFAs) can enhance the antioxidative properties including the activity of glutathione peroxidase and reduced serum lipid peroxidation in experimental animals (Ebeid et al., 2008). Simopoulos (2000) reported that the recommended ratio of n-6/n-3 PUFA is 4:1 to 10:1 in the diet of human and the author demonstrated that the diet of our ancestors contained roughly equal amounts of n-6 and n-3 PUFA, while the modern diet of community is very high in n-6 PUFA, and the intake of n-3 PUFA is much lower because of decreased fish consumption, and also the industrial production of animal feeds rich in grains containing n-6 PUFA resulting the meat production rich in n-6 PUFA, but poor in n-3 PUFA. It will be necessary to decrease the intake of n-6 PUFA and increase the intake of n-3 PUFA. The food industry is already taking steps to return n-3 PUFA to the food supply by enriching various foods like meat, eggs, milk and milk products with n-3 PUFA. Pomegranate peel (POM) attracts attention due to its apparent woundhealing properties (Chidambara et al., 2004), immunomodulatory activity (Gracious et al., 2001), antibacterial activity (Navarro et al., 1996), and antiatherosclerotic and antioxidative capacities (Tzulker et al., 2007). Antioxidative activity has often been associated with a decreased risk of various diseases and mortality. Singh et al. (2009) and Zeweil et al. (2012) reported that POM is a good source of antioxidants. Li et al. (2006) reported that POM offers higher yields of phenolics, flavonoids and proanythocyanidins than the pulp. Flavonoid content was significantly greater in the peel than the pulp (59 versus $17 \mathrm{mg} / \mathrm{g}$ ), as were proanythocyanidins (11 versus $5 \mathrm{mg} / \mathrm{g}$ ). Also, peel extract acted more dramatically in protecting LDL against oxidation as compared to the pulp extract. Oxidation of LDL has been proposed to play a key role in the hardening of the arteries (atherosclerosis). Moreover, the most synthetic antioxidants have been restricted recently, mainly because of their possible carcinogenesis effect (Mhdavi and Salunkhe, 1995), causing liver swelling and changing liver enzyme activities (Martin and Gilbert, 1968). The present study aimed to investigate the growth performance, meat $n-3$ and n-6 fatty acids, immunological effects, lipid peroxide and the antioxidative status resulting from supplemented the linseed oil in diets of growing V-line rabbits with two levels of pomegranate peel under summer contrition.

\section{MATERIALS AND METHODS}

Forty-eight growing V-line rabbits of both sexes, 7 weeks old, with initial weights of $982.75 \pm 15.85 \mathrm{~g}$ were used for the study during the period of June to August 2015. The rabbits were randomly allocated to four groups of 12 rabbits each. Each group was further sub-divided into 4 replicates of 3 rabbits. Rabbits were housed in wire floor batteries of $45 \times 36 \times 36 \mathrm{~cm}$ and were offered diets for duration of the feeding trial until reaching 15 weeks of age. All rabbits were kept under similar hygienic conditions, under ambient temperature ranged from 26.3 to $31.5^{\circ} \mathrm{C}$; relative humidity ranged from 70.28 to $78.4 \%$ and temperature humidity index (THI) ranged from 25.20 to 30.35 according to Marai et al. (2002). The estimated temperature-humidity index value indicated that during the experimental period rabbit bucks were exposed to severe heat stress. Rabbits were housed in well ventilated block building, fresh air was circulated in the house using exhaust fans. The rabbits were kept within a cycle of $16 \mathrm{~h}$ light and $8 \mathrm{~h}$ dark. Five pelleted diets were prepared. Group 1 fed a pelleted basal diet with standard components (control group), group 2 fed a pelleted diet containing $2 \%$ linseed oil, group 3 fed a pelleted diet containing $2 \%$ linseed oil plus $0.75 \%$ POM and group 4 fed a pelleted diet containing $2 \%$ linseed oil plus $1.5 \%$ POM. The experimental diets were feed for 8 weeks. Linseed oil was purchased from local company (Alexandria Company for extracted oils, Alexandria Governorate, Egypt). Pomegranate fruits were obtained from local market, their peels (POM) were washed well in running water and were dried in the sun for $96 \mathrm{~h}$. then the dried peels were grounded using coffee grinder. Some modifications were done in the composition of the basal diets to make the four experimental diets isonitrogenous and isoenergetic containing approximately $17 \%$ crude protein; $12 \%$ crude fiber and 2744 digestible energy (Table 1). Each group of rabbits was fed one of four experimental diets. Fresh water was automatically available at all times through stainless steel nipples for each cage. The experimental diets were offered to rabbits ad libitum. 
Table (1): Composition and chemical analyses of the experimental diets.

\begin{tabular}{|c|c|c|c|c|}
\hline Item & Control & $\begin{array}{l}\text { Linseed } \\
\text { oil }\end{array}$ & $\begin{array}{c}\text { Linseed oil }+0.75 \% \\
\text { POM }\end{array}$ & $\begin{array}{c}\text { Linseed oil+ } 1.5 \% \\
\text { POM }\end{array}$ \\
\hline \multicolumn{5}{|l|}{ Ingredients\%: } \\
\hline Yellow corn & 18.90 & 16.90 & 16.90 & 16.90 \\
\hline Wheat bran & 11.00 & 11.00 & 11.00 & 11.00 \\
\hline Barley & 17.30 & 17.30 & 17.30 & 17.30 \\
\hline Alfalfa meal & 28.00 & 28.00 & 27.25 & 26.50 \\
\hline Soybean meal (44\%) & 20.00 & 20.00 & 20.00 & 20.00 \\
\hline Molasses & 3.00 & 3.00 & 3.00 & 3.00 \\
\hline Di-calcium phosphate & 1.00 & 1.00 & 1.00 & 1.00 \\
\hline Dl- methionine & 0.10 & 0.10 & 0.10 & 0.10 \\
\hline L-lysine & 0.10 & 0.10 & 0.10 & 0.10 \\
\hline Vit, and min. mix. ${ }^{1}$ & 0.30 & 0.30 & 0.30 & 0.30 \\
\hline $\mathrm{Nacl}$ & 0.30 & 0.30 & 0.30 & 0.30 \\
\hline Linseed oil & - & 2.00 & 2.00 & 2.00 \\
\hline Pomegranate peel & - & - & 0.75 & 1.50 \\
\hline Total & 100 & 100 & 100 & 100 \\
\hline \multicolumn{5}{|l|}{ Chemical analysis $^{2}$ : } \\
\hline Crude protein $\%$ & 17.19 & 17.04 & 17.02 & 17.00 \\
\hline Crude fiber $\%$ & 12.44 & 12.39 & 12.26 & 12.13 \\
\hline Ash\% & 7.56 & 7.50 & 7.81 & 7.83 \\
\hline Ether extract $\%$ & 3.82 & 3.91 & 3.89 & 3.85 \\
\hline Digestible energy $^{3}$ (kcal/kg DM) & 2755.80 & 2766.09 & 2725.56 & 2726.91 \\
\hline \multicolumn{5}{|c|}{ 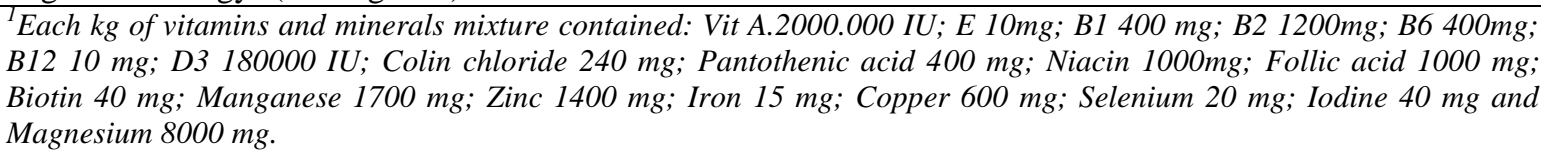 } \\
\hline \multicolumn{5}{|l|}{${ }^{2}$ Analyzed according to AOAC (2005). } \\
\hline
\end{tabular}

Individual body weight and feed consumption were recorded weekly. Daily body weight gain and feed conversion ratio were also calculated. The incidence of dangerous diseases was largely avoided and rabbits have never been treated with any kind of systematic vaccination or medication. Three rabbits of each treatment were immunized with $0.1 \mathrm{ml}$ of $2.5 \%$ sheep red blood cells (SRBC) at 15 days after starting the dietary treatment supplementation, to measure antibody titer against SRBC. The dosage of SRBC for inoculation was pre-determined by a separate trial. Antiserum to SRBC was collected 7, 14 and 21 days post challenge according to Wegmann and Smithies (1966). The agglutination titer was expressed as the $\log ^{2}$ of the reciprocal of the highest serum dilution giving complete agglutination (Nelson et al., 1995). At the end of the feeding trial, 3 rabbits were selected from each treatment group randomly, starved of food, but not water for 12 hours and slaughtered for carcass analysis. Before slaughtering, $6 \mathrm{ml}$ of blood sample was taken from the ear vein with a sterile syringe, $3 \mathrm{ml}$ of the blood was put into a bijon bottle containing ethylene diaminetetracetic acid (EDTA) as an anticoagulant for hematological assay. The remaining $3 \mathrm{ml}$ of the blood sample was put into a sterile vacutainer tube without an anticoagulant for serum biochemical analysis. The hematological assay was carried out to determine erythrocyte indices such as packed cell volume (PCV), and hemoglobin $(\mathrm{Hb})$ values. Red blood cell (RBC) counts were counted according to Natt and Herrick (1952). White blood cell (WBC) was counted according to Hepler (1966). Platelets (PLT) were counted according to Becton-Dickinson (1996). Total lipids, triglycerides, cholesterol, low density lipoprotein (LDL), high density lipoprotein (HDL), total antioxidant capacity (TAC) and malondialdehyde(MAD) concentrations in serum were estimated using commercial kits (Bio Merieux, France) according to the procedure outlined by the manufacturer. Serum immunoglobulin ( $\mathrm{IgG})$ was determined using ELISA technique. Fatty acids were extracted from hind leg muscle tissue of rabbits, omega 3 and 6 were analyzed by using gas chromatography 
(GLC) according to the method described by Radwan (1978). Muscle cholesterol was determined by method of Richmond (1973), by using cholesterol CHOD-PAP Kitswhich produced by Human, Germany.

Results were expressed as the mean \pm SE. All data were analyzed using one way analysis of variance (ANOVA) using SPSS 11.0 statistical software (SPSS, Inc., Chicago, Il, 2001). Significant differences between means were detected using Duncan multiple range test (Duncan, 1955).

\section{RESULTS AND DISCUSSION}

The effects of linseed oil without or with different levels of pomegranate peel (POM) on growth performance of growing rabbits are summarized in Table (2). The different experimental treatments had insignificant effect on final body weight and daily body weight gain, however, significant $(P \leq 0.05)$ decrease in daily feed intake and significant $(\mathrm{P} \leq 0.05)$ improvement in feed conversion were recorded in comparison with the control group. Differences among the supplemented groups on daily feed intake and feed conversion ratio were not found.

Table (2): Effect of linseed oil without or with different levels of pomegranate peel on rabbits growth performance.

\begin{tabular}{lccccc}
\hline Treatments & $\begin{array}{c}\text { Initial } \\
\text { body weight } \\
(\mathrm{g})\end{array}$ & $\begin{array}{c}\text { Final } \\
\text { body weight } \\
(\mathrm{g})\end{array}$ & $\begin{array}{c}\text { Daily } \\
\text { weight gain } \\
(\mathrm{g})\end{array}$ & $\begin{array}{c}\text { Daily } \\
\text { feed intake } \\
(\mathrm{g})\end{array}$ & $\begin{array}{c}\text { Feed } \\
\text { conversion } \\
\text { ratio }\end{array}$ \\
\hline Control & $992.10 \pm 15.10$ & $2262.50 \pm 63.51$ & $22.62 \pm 1.19$ & $75.12^{\mathrm{a}} \pm 1.38$ & $3.33^{\mathrm{a}} \pm 0.07$ \\
Linseed oil 2\% & $991.80 \pm 17.00$ & $2250.00 \pm 47.32$ & $22.40 \pm 0.77$ & $64.98^{\mathrm{b}} \pm 0.79$ & $2.90^{\mathrm{b}} \pm 0.06$ \\
Linseed oil 2\% + 0.75\% POM & $971.31 \pm 12.42$ & $2230.61 \pm 54.51$ & $22.41 \pm 0.64$ & $65.02^{\mathrm{b}} \pm 1.50$ & $2.90^{\mathrm{b}} \pm 0.09$ \\
Linseed oil 2\% + 1.5 \% POM & $975.83 \pm 18.91$ & $2279.33 \pm 50.80$ & $23.18 \pm 0.89$ & $64.62^{\mathrm{b}} \pm 0.83$ & $2.86^{\mathrm{b}} \pm 0.18$ \\
\hline \multicolumn{7}{l}{ Different letters $(a$ and $b)$ within a column denote significant differences between treatments } \\
\hline
\end{tabular}

Different letters ( $a$ and $b$ ) within a column denote significant differences between treatments $(P \leq 0.05)$.

These results are in agreement with those presented by Saleh et al. (2013) showed that linseed oil has no significant effect on body weight, daily weight gain and daily feed intake of male growing New Zealand white rabbits. Furthermore, Trebušak et al. (2011) indicated that body weight gain was not influenced when the rabbits fed diets containing linseed oil, while feed intake was significantly reduced and feed conversion ratio was improved. In addition, the obtained results were in agreement with those of Hussein and Shujaa (2013) reported that the final body weight did not have any change when lambs fed pomegranate peel at the rate 2, 4 and $6 \%$. On the other hand, Sadq et al. (2016) reported that final body weight was significantly (P < 0.05) higher in lambs fed 1 or $2 \%$ POM as compared to lambs fed 4\% POM or control diet. Also, Zeweil et al. (2012) showed that rabbits reared under stress summer conditions and fed diets containing different levels of pomegranate peel $(1.5,3$ and $4.5 \%)$ had higher $(\mathrm{P}=0.0001)$ body weight and feed conversion values, while those fed control diet had the lower values in the fourth and eights week of treatment. Mahmoud et al. (2011) reported that POM contains considerable amounts of polyphenols together with the high fiber content which reduced food consumption. Also, the results of Sadq et al. (2016) indicated that the best improvement in feed conversion ratio was found in lambs fed 1\% POM as compared with control or the groups fed 2 and 4 $\%$ POM. Digestive disorders of weaned rabbits were prevented by POM, moreover severity of diarrhea was not observed by POM including in the diet. The results of Liuab et al., 2011, recorded that addition of chestnut tannins had a favorable effect on feed conversion ratio of heat stressed rabbits. Also, Vakili et al. (2010) showed that antioxidants significantly improved feed conversion ratio of heat stressed broilers. Generally, Murthy et al. (2004) and Ajaikumar et al. (2005) stated that the polyphenols in the pericarp of pomegranate can significantly improve the healing of gastric alcer with curative ratio of $97.4 \%$. This effect is believed to be related to the astringent property of tannins which are able to bind with protein so as to accelerate with the healing of ulcer or trauma. However, this protective effect may also correlate with the antibacterial activity of the pericarp, because the aqueous extract of the pericarp significantly inhibited the growth of Helicobacter pylori (Hu et al., 2006). Both organic extract and aqueous extract of the pericarp exhibited anti-diarrhea activity for which the antibacterial effect against E. coli, Shigellasonnei, S. flexneri and Salmonella typhiof hydrolysable tannins may be responsible (Mathabe et al., 2006). Also, another explanation supported by Li et al. (2003) who found that the extract of pomegranate leaves abundant with tannins was demonstrated to be a good gastric protective agent, increase the activity of pepsin, improve the 
secretion of bile, enhance the intestine peristalsis, inhibit the secretion of gastric acid and dispel intestinal parasite by continual intestinal tract concentration. Besides, pomegranate extract inclusion significantly enhanced the growth of Bifidobacterium breve and Bifidobacter iuminantis which conceder a good probiotic essential for good health in both babies and adults (Viuda-Martos et al., 2010).

Results for pre-slaughter weight and percentage of hot carcass and liver were insignificantly affected by different treatments in comparison with control. Pomegranate peel treatments significantly $(\mathrm{P}<0.05)$ decreased abdominal fat weight, in comparison with the control group and linseed oil only, the different treatments showed significant decrease in the muscle total cholesterol in comparison with the control group (Table 3). Salama (2011) reported that linseed oil had insignificant effect on pre-slaughter weight of rabbits at 13 weeks of age. Saleh et al. (2013) reported that carcass weight, dressing percentage and liver weight were increased; however, abdominal fat weight was decreased by dietary supplementation of linseed oil with organic selenium. The results of Zeweil et al. (2012) showed that the POM had no significant effect on the percentages of carcass percent, fur, head, kidney, kidney fat, heart, liver, spleen and caecum.

Table (3): Effect of linseed oil without or with different levels of pomegranate peel on rabbits carcass traits.

\begin{tabular}{lccccc}
\hline Treatments & $\begin{array}{c}\text { Pre-slaughter } \\
\text { weight }(\mathrm{g})\end{array}$ & $\begin{array}{c}\text { Hot } \\
\text { carcass \% }\end{array}$ & $\begin{array}{c}\text { Liver } \\
\%\end{array}$ & $\begin{array}{c}\text { Abdominal } \\
\text { fat weight \% }\end{array}$ & $\begin{array}{c}\text { Muscle total cholesterol } \\
(\mathrm{mg} / 100 \mathrm{~g} \text { muscle })\end{array}$ \\
\hline Control & $2245.00 \pm 65.00$ & $50.55 \pm 4.21$ & $2.22 \pm 0.04$ & $2.45^{\mathrm{a}} \pm 0.19$ & $69.33^{\mathrm{a}} \pm 3.53$ \\
Linseed oil 2\% & $2231.70 \pm 14.24$ & $49.19 \pm 2.81$ & $2.19 \pm 0.22$ & $2.17^{\mathrm{a}} \pm 0.12$ & $57.00^{\mathrm{b}} \pm 2.08$ \\
Linseed oil 2\%+0.75\% POM & $2253.32 \pm 24.04$ & $50.56 \pm 2.23$ & $2.08 \pm 0.46$ & $1.80^{\mathrm{b}} \pm 0.09$ & $51.33^{\mathrm{b}} \pm 4.10$ \\
Linseed oil 2\%+1.5\% POM & $2333.31 \pm 76.88$ & $52.22 \pm 2.09$ & $2.54 \pm 0.27$ & $1.74^{\mathrm{b}} \pm 0.04$ & $49.67^{\mathrm{b}} \pm 0.33$ \\
\hline
\end{tabular}

Different letters ( $a$ and $b$ ) within a column denote significant differences between treatments $(P \leq 0.05)$.

Results illustrated in Table (4) showed the effect of linseed oil without or with different levels of pomegranate peel on $n-3, n-6$ and the ratio $n-3 / n-6$ of the hind leg muscle fat. It was observed that the $n-3$ fatty acids and $n-3 / n-6$ ratio were significantly $(P \leq 0.05)$ increased by feeding linseed oil and linseed oil plus pomegranate peel, while the n- 6 fatty acids were decreased significantly by feeding linseed oil and linseed oil plus pomegranate peel treatments in comparison with control. These results suggest that the addition of linseed oil with pomegranate peel could be recommendable to increase n-3 PUFA in rabbit meats, providing a healthier and functional rabbit meat to consumer. The change of lipid composition of animal feeds can have an impact on the nutritional value of the meat consumed by the humans (Bourre, 2005). Feeding rabbits with diets containing sunflower or linseed oil rich in PUFAs considerably improves polyunsaturated/saturated ratio, increases the $\alpha$-linolenic and linoleic level as well as increases the $\mathrm{n}-3 / \mathrm{n}-6$ ratio in the muscles (Zsédely et al., 2006). Trebušak et al. (2011) found that linoleic acid and $\alpha$-linolenic acid were increased while; palmatic acid was decreased when rabbits fed diet contained linseed oil and consecutively caused a significant decrease in the n-6/n-3 PUFA ratio. Similarly, Peiretti (2012) reported that feeding rabbits with linseed oil increased unsaturated fatty acids, while saturated fatty acids were decreased.

Table (4): Effect of linseed oil without or with different levels of pomegranate peel on $n-3, n-6$ and $n-3 /$ $\mathrm{n}-6$ ratio of the muscle tissue lipids in the rabbits hind leg $(\mathrm{g}$ per $100 \mathrm{~g}$ of all acids determined).

\begin{tabular}{lccc}
\hline Treatments & $\mathrm{n}-3$ & $\mathrm{n}-6$ & $\mathrm{n}-3 / \mathrm{n}-6$ \\
\hline Control & $1.31^{\mathrm{d}} \pm 0.01$ & $7.63^{\mathrm{a}} \pm 0.36$ & $0.17^{\mathrm{b}} \pm 0.01$ \\
Linseed oil 2\% & $3.68^{\mathrm{c}} \pm 0.30$ & $4.46^{\mathrm{b}} \pm 0.27$ & $0.82^{\mathrm{a}} \pm 0.02$ \\
Linseed oil 2\%+0.75\% POM & $4.30^{\mathrm{b}} \pm 0.12$ & $5.93^{\mathrm{b}} \pm 0.47$ & $0.73^{\mathrm{a}} \pm 0.04$ \\
Linseed oil 2\%+1.5\% POM & $4.91^{\mathrm{a}} \pm 0.09$ & $5.84^{\mathrm{b}} \pm 0.65$ & $0.86^{\mathrm{a}} \pm 0.09$ \\
\hline
\end{tabular}

Different letters (a, b, c and d) within a column denote significant differences between treatments $(P \leq 0.05)$. 
Results of hematological parameters of the rabbits in Table (5) showed insignificant effect on hematocrit, RBCs, WBCs, $\mathrm{Hb}$ and platelets of rabbits fed different experimental diets in comparison with control.

Table (5): Effects of linseed oil without or with different levels of pomegranate peel on rabbits blood hematology.

\begin{tabular}{lccccc}
\hline \multirow{2}{*}{ Treatments } & RBCs & WBCs & Hb & PCV & PLT \\
& $10^{6} / \mathrm{mm}^{3}$ & $10^{3} / \mathrm{mm}^{3}$ & $\mathrm{mg} / \mathrm{dl}$ & $\%$ & $10^{3} / \mathrm{mm}^{3}$ \\
\hline Control & $6.49 \pm 0.19$ & $4.93 \pm 0.66$ & $12.60 \pm 0.53$ & $44.27 \pm 1.24$ & $348.67 \pm 17.85$ \\
Linseed oil 2\% & $6.52 \pm 0.33$ & $5.97 \pm 0.55$ & $13.03 \pm 0.49$ & $44.93 \pm 1.24$ & $443.00 \pm 28.58$ \\
Linseed oil 2\%+0.75\% POM & $6.63 \pm 0.11$ & $5.83 \pm 0.77$ & $13.20 \pm 0.32$ & $45.87 \pm 1.32$ & $405.00 \pm 28.31$ \\
Linseed oil 2\%+ 1.5\% POM & $6.47 \pm 0.24$ & $4.30 \pm 0.51$ & $12.73 \pm 0.32$ & $44.03 \pm 0.97$ & $443.33 \pm 30.27$ \\
\hline
\end{tabular}

Antibody titers against sheep red blood cells (SRBCs) determined are shown in Table (6) as affected by linseed oil and with different levels of pomegranate peel in comparison with the control group. Antibody titters against SRBCs at 14, 21 and 28 days were insignificantly affected by different treatments. The level of specific IgG (Fig.1) together with the intensity of delayed-type hypersensitivity to sheep erythrocytes were investigated in rabbits fed with different treatments load for a month. It is shown that linseed oil and different levels of POM were significantly an immunomodulatory. On the other hand, Zeweil et al. (2012) showed that feeding diets containing $1.5 \%$ POM to rabbits resulted in inducing insignificant increase in hemagglutination inhibition test (HI) against SRBCs reached to $124.4 \%$ of control value. However, 3 and $4.5 \%$ POM resulted in inducing significant $(\mathrm{p}=0.001)$ increase in $\mathrm{HI}$ against SRBCs reached to 130.7 and $171.7 \%$, respectively, compared with control values. The present results are in concurrence with Gracious et al. (2001) who evaluating Punica granatum fruit rind powder at dose of $100 \mathrm{mg} / \mathrm{Kg}$ and found stimulation in the cellmediated and humoral components on the immune system of rabbits. Furthermore, Oliveira et al. (2010), found that salivary IgA secretion was increased in those subjects supplemented with polyphenols, which indicated a positive effect on mucosal immunity.

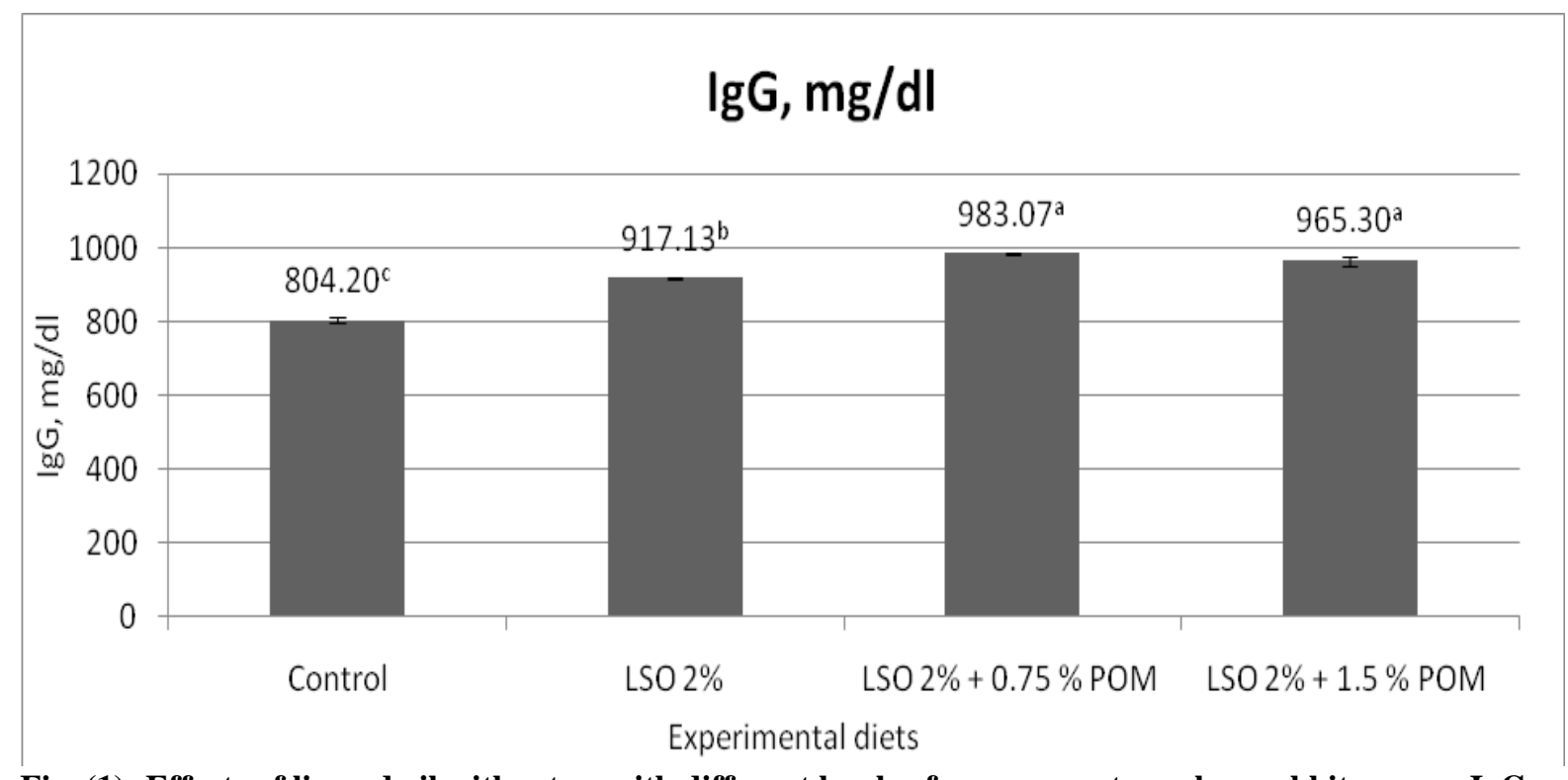

Fig. (1): Effects of linseed oil without or with different levels of pomegranate peel on rabbits serum IgG. 
Table (6): Effect of linseed oil without or with different levels of pomegranate peel on sheep RBCs antibody titer of rabbits.

\begin{tabular}{lccc}
\hline Treatments & 14 days & 21 days & 28 days \\
\hline Control & $0.913 \pm 0.032$ & $0.819 \pm 0.054$ & $0.885 \pm 0.074$ \\
Linseed oil 2\% & $0.887 \pm 0.026$ & $0.834 \pm 0.058$ & $0.887 \pm 0.026$ \\
Linseed oil 2\%+0.75\% POM & $0.920 \pm 0.012$ & $0.960 \pm 0.042$ & $0.870 \pm 0.038$ \\
Linseed oil 2\%+1.5\% POM & $0.911 \pm 0.039$ & $0.975 \pm 0.030$ & $0.913 \pm 0.032$ \\
\hline
\end{tabular}

Results illustrated in Table (7) showed the effect of different treatments on blood serum lipid profile. It was observed that serum total lipids and low density lipoprotein were significantly $(\mathrm{P} \leq 0.05)$ decreased due to different experimental diets in comparison with the control group. However, it was observed that total cholesterol was decreased, while triglycerides was increased in animals received linseed oil only in their diet, while pomegranate peel supplement had insignificant effect on total cholesterol and triglycerides in comparison with control.

Table (7): Effect of linseed oil without or with different levels of pomegranate peel on blood serum lipid profile of rabbits.

\begin{tabular}{|c|c|c|c|c|c|c|}
\hline Treatments & $\begin{array}{c}\text { Total lipids } \\
\text { mg/dl }\end{array}$ & $\begin{array}{l}\text { Triglycerides } \\
\mathrm{mg} / \mathrm{dl}\end{array}$ & $\begin{array}{c}\text { Total } \\
\text { cholesterol } \\
\mathrm{mg} / \mathrm{dl}\end{array}$ & $\begin{array}{l}\mathrm{HDL}^{1} \\
\mathrm{mg} / \mathrm{dl}\end{array}$ & $\begin{array}{l}\mathrm{LDL}^{2} \\
\mathrm{mg} / \mathrm{dl}\end{array}$ & HDL/LDL \\
\hline \multirow{2}{*}{ Control } & $376.6^{\mathrm{a}}$ & $65.83^{b}$ & $98.20^{\mathrm{a}}$ & $17.37^{\mathrm{d}}$ & $25.40^{\mathrm{a}}$ & $0.69^{\mathrm{c}}$ \\
\hline & \pm 4.1 & \pm 6.39 & \pm 18.99 & \pm 0.11 & \pm 0.30 & \pm 0.00 \\
\hline Linseed oil $2 \%$ & $\begin{array}{l}344.2^{\mathrm{b}} \\
+133\end{array}$ & $119.67^{\mathrm{a}} \pm 15.76$ & $\begin{array}{c}52.97^{\mathrm{b}} \\
+766\end{array}$ & $27.36^{\mathrm{c}}$ & $11.77^{\mathrm{c}}$ & $2.33^{\mathrm{b}}$ \\
\hline \multirow{2}{*}{ Linseed oil $2 \%+0.75 \%$ POM } & $320.7^{\mathrm{c}}$ & $76.60^{\mathrm{b}}$ & $\begin{array}{l} \pm .06 \\
75.90^{\mathrm{ab}}\end{array}$ & $34.23^{\mathrm{b}}$ & $\begin{array}{l} \pm 0.2 \mathrm{o} \\
14.45^{\mathrm{b}}\end{array}$ & $\begin{array}{l} \pm 0.04 \\
2.37^{\mathrm{b}}\end{array}$ \\
\hline & \pm 1.4 & \pm 9.63 & \pm 1.32 & \pm 0.59 & \pm 0.32 & \pm 0.06 \\
\hline \multirow{2}{*}{ Linseed oil $2 \%+1.5 \%$ POM } & $337.5^{\mathrm{bc}}$ & $77.17^{b}$ & $77.33^{\mathrm{ab}}$ & $38.68^{\mathrm{a}}$ & $13.05^{\mathrm{bc}}$ & $2.97^{\mathrm{a}}$ \\
\hline & \pm 4.7 & \pm 4.76 & \pm 7.60 & \pm 0.24 & \pm 0.59 & \pm 0.12 \\
\hline
\end{tabular}

Different letters ( $a, b, c$ and $d)$ within a column denote significant differences between treatments $(P \leq 0.05)$.

${ }^{1} H D L=$ High density lipoprotein, ${ }^{2} L D L=$ Low density lipoprotein.
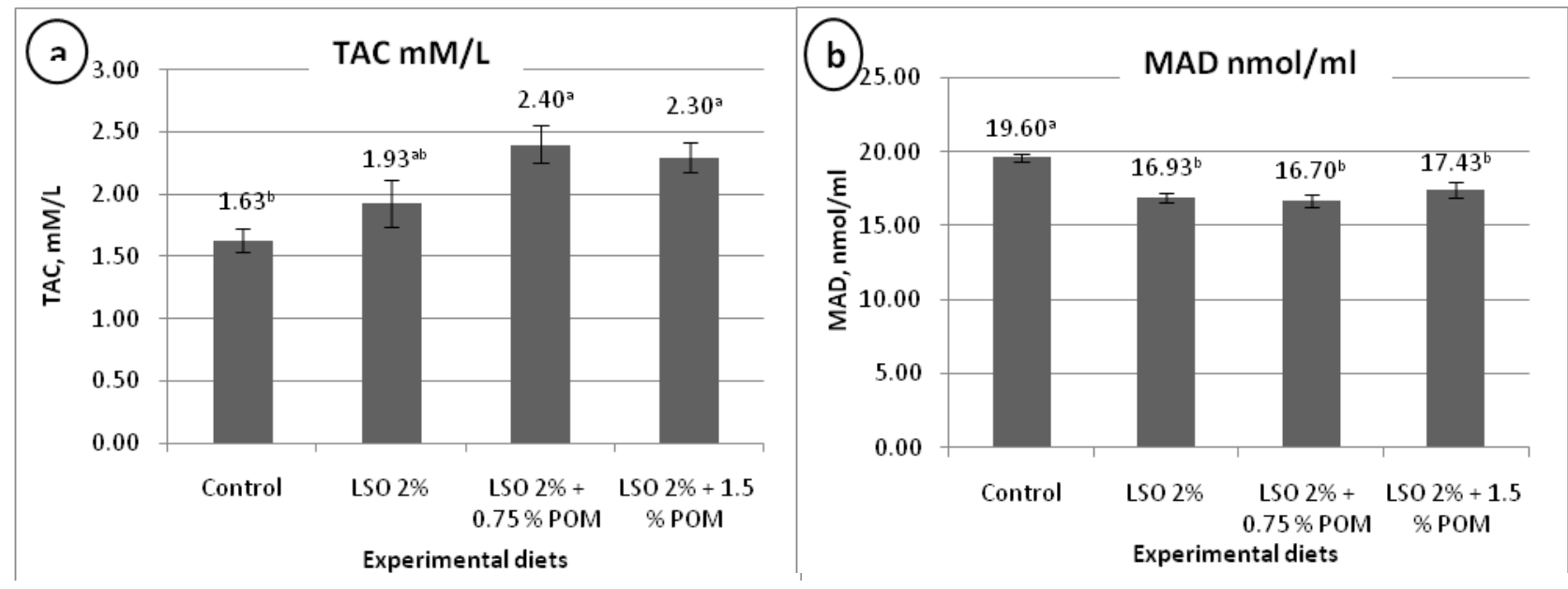

Fig: (2). Effect of linseed oil without or with different levels of pomegranate peel on (a) serum total antioxidant capacity (TAC) and (b) serum malondialdehyde (MAD) of rabbits. 
High density lipoprotein concentration and HDL/LDL ratio were significantly $(\mathrm{P} \leq 0.05)$ increased by different experimental treatments as compared with the control group. Saleh et al. (2013) showed that dietary supplementation of linseed oil with or without organic selenium decreased plasma total cholesterol and LDL, while, plasma HDL and glutathione peroxidase were increased in linseed oil plus organic selenium. Zeweil et al. (2016) showed that serum total lipids, total cholesterol and triglycerides were significantly $(\mathrm{P} \leq 0.01)$ reduced due to addition of 100 or $200 \mathrm{mg}$ lycopene, as a natural antioxidant in growing rabbit diets in comparison with the control group.

Exposing growing rabbits to high temperature conditions during summer season resulted in significant decrease $(\mathrm{P} \leq 0.05)$ in serum total antioxidant capacity and elevated serum MDA which was obtained in the control group. However, including linseed oil or linseed oil plus 0.75 and $1.5 \%$ POM appeared to antagonize the effect of high temperature during summer (Fig. 2). The total antioxidant capacity in blood serum of rabbits fed linseed oil plus 0.75 and $1.5 \%$ POM was increased by about 47.24 and $41.10 \%$, respectively as compared with the control group. However, linseed oil, 0.75 and $1.5 \%$ POM supplementation significantly reduced lipid peroxidation in serum expressed as serum malondialdehyde (MDA) by 13.62, 14.80 and11.73\%, respectively; in comparison with the control one free of linseed oil and POM. Heat stress through summer conditions causes increased free radical production (Halliwell and Gutteridge, 1989) and decreased the concentrations of antioxidant vitamins and minerals such as E, C, A and $\mathrm{Zn}$ in serum and tissues (Sahin and Kucuk, 2003). Free radicals trigger the metabolic disorder, cell death and growth retardation (Okada, 1996). Salama (2011) showed that dietary treatment with $2 \%$ linseed oil and/ or $0.5 \%$ green tea significantly increased total antioxidant capacity, superoxide dismutase and glutathione peroxidase activity, however, MDA concentration was significantly reduced comparing to the control group. Zeweil et al. (2016) showed that exposing growing rabbits to high temperature conditions during summer season resulted in significant decrease $(\mathrm{P} \leq 0.05)$ in serum total antioxidant capacity which was obtained in the control group, however, supplementation of 100 or $200 \mathrm{mg}$ lycopene / $\mathrm{kg}$ of growing rabbit diets as antioxidant appeared to antagonize the effect of high temperature. The different levels of lycopene $(100 \mathrm{and} 200 \mathrm{mg})$ increased total antioxidant capacity in blood serum by 51.9 and $49.4 \%$, respectively in comparison with the control group.

The dietary composition may alter metabolism and physical activity, resulting in body temperature change. It is suggested that quantitative changes in dietary fat content are capable altering physiological mechanism, which mediate indices including thermogenesis in rats (Yehuda et al., 1986). Thermogenesis affects the energy expenditure and energetic efficiency in mammals (Rothwell and Stock, 1983).

\section{CONCLUSION}

It is concluded that dietary supplementation of linseed oil plus Pomegranate peel in growing rabbit's diets had a beneficial effect on the composition of the meat lipid fraction by increasing the concentration of n-3 fatty acids and improving the feed conversion, blood serum lipid profile and antioxidant status.

\section{REFERENCES}

Ajaikumar, K. B., M. Asheef, B. H. Babu and J. Padikkala (2005). The inhibition of gastric mucosal injury by Punica granatum L. (pomegranate) methanolic extract. J. Ethnopharmacol, 96: 171-176.

AOAC (2005). Association of Official Analytical Chemist, Official Methods of Analysis. $18^{\text {th }}$ Edn. International Maryland, USA.

Becton-Dickinson (1996). Unopette WBC/Platelet determination for manual methods. Rutherford, N.J.: Becton, Dickinson, and Company.

Bourre, J. M. (2005). Effect of increasing the omega-3 fatty acid in the diets of animals on the animal products consumed by humans. Med. Sci. (Paris), 21: 773-779. 


\section{Egyptian J. Nutrition and Feeds (2016)}

Chidambara, M. K., V. K. Reddy, J. M. Veigas and U. D. Murthy (2004). Study on wound healing activity of Punicagranatum peel. Journal of Medical Food, 7: 256-259.

Das R., L. Sailo, N. Verma, Bharti., Saikia J. Imtiwati and R. Kumar (2016). Impact of heat stress on health and performance of dairy animals: A review, Veterinary World. 9, 3: 260-268.

Duncan, D. B. (1955): Multiple Range and Multiple F tests. Biometrics, 11: 1-42.

Ebeid, T., Y. Eid, A. Saleh and H. Abd El-Hamid (2008). Ovarian follicular development, lipid peroxidation, antioxidative status and immune response in laying hens fed fish oil-supplemented diets to produce n-3enriched eggs. Animal, 2:1, 84-91.

Fekete, S. and T. Gippert (1986). Digestibility and nutritive value of nineteen important feedstuffs for rabbits. J. Applied. Rabbit Res., 9, 3: 103-108.

Gracious, R. R., S. Selvasubramanian and S. Jayasundar (2001). Immunomodulatory activity of Punica granatum in rabbits. A preliminary study. J. Ethnopharmacol., 78: 85-87.

Halliwell, B. E. and J. M. C. Gutteridge (1989). Lipid peroxidation: a radical chain reaction. In: Free Radicals in Biology and Medicine, $2^{\text {nd }}$ ed. Oxford University Press, New York, NY, pp. 188-218.

Hepler, O. E. (1966). Manual of Clinical Laboratory Methods. Thomas Spring Field. Illinois.

Hu, W., Y. Dai, M. Yang, Z. F. Zhau, X. Y. Li and L. P. Duan (2006). Study of In vitro inhibition effect of pomegranate rind on H. pylori. Academic. Journal of Kunming Medical College, 27: 25-27.

Hussein, S.A.M. and T. A. Shujaa (2013). The effect of using different ratios of pomegranate peels in performance and digestibilties in Awassi lambs. Journal of Tikrit University for Agricultural Sciences, $13,52-62$.

Lee, C.Y. (2002). Explaining just how vitamin C works against cancer. The Lancet, 359: 9301-9305.

Li, D.G., Z. M. Zhang and X. J. Chen (2003). Study on the influence of aqueous extract of leaves of Punica granatum on the secretion of gastric acids and experimental gastric ulcer. Chinese Journal of Preventive Medicine, 19: 23-24.

Li, Y., C. Guo, J. Yang, J. Wei, J. Xu and S. Cheng (2006). Evaluation of antioxidant properties of pomegranate peel extract in comparison with pomegranate pulp extract. Food Chemistry, 96: 254-260.

Liuab, H. W., X. F. Donga, J. M. Tonga and Q. Zhanga (2011). A comparative study of growth performance and antioxidant status of rabbits when fed with or without chestnut tannins under high ambient temperature. Animal Food Science and Technology, 164, 1: 89-95.

Mahmoud, M. H., S. S. Kassem, M. M. Abdel-Kader and F. A. El-Shobaki (2011). How to reduce weight and keep. Int. J. Acad. Res., 3: 126-132.

Marai, I.F.M., A. A. M. Habeeb and A. E. Gad (2002). Rabbits productive, reproductive and physiological performance traits as affected by heat stress: a review. Livestock Production Science, 78: 71-90.

Martin A. D. and D. Gilbert (1968). Enzyme change accompanying liver enlargement in rats treated with 3tert-butyl-4-hydroxyanisole. Biochemical Journal, 106: 22-23.

Mathabe, M. C., R. V. Nikolova, N. Lall and N. Z. Nyazemac (2006). Antibacterial activities of medicinal plants used for the treatment of diarrhea in Limpopo Province, South Africa. Journal of Ethnopharmacology, 105: 286-293.

Mhdavi, D. L. and D. K. Salunkhe (1995). Toxicological aspects of food antioxidant. In: Mhdavi D. L., Deshpande S. S., Salunkhe D. K. "Food Antioxidants", (Eds.) Marcel Dekker, New York.

Murthy, K. N., V. K. Reddy, J. M. Veigas and U. D. Murthy (2004). Study on wound healing activity of Punica granatum peel. J Med. Food, 7: 256-259.

Natt, M. P. and C. A. Herrick (1952). A new blood diluent for counting erythrocytes and leucocytes of the chicken. Poultry Science, 31, 735-738. 
Navarro, V., M.L.Villarreal, G.Rojas and X. Lozoya (1996). Antimicrobial evaluation of some plants used in Mexican traditional medicine for the treatment of infectious diseases. Journal of Ethnopharmacology, 53: $143-147$.

Nelson, N.N., N. Lakshmanan and S. J. Lamont (1995). Sheep red blood cell and Brucella abortus antibody responses in chickens selected for multitrait immunocompetence. Poultry Science. 74:1603-1609.

Okada, S. (1996). Iron-induced tissue damage and cancer: The role of reactive oxygen species-free radicals. Pathology International, 46: 311-332.

Oliveira, R.A., C. D. Narciso, R. S. Bisinotto, M. C. Perdomo, M. A. Ballou, M. Dreher and J. E. Santos (2010). Effects of feeding polyphenols from pomegranate extract on health, growth, nutrient digestion, and immunocompetence of calves. J. Dairy Sci., 93, 9: 4280-4291.

Peiretti, P.G. (2012). Effects of dietary fatty acids on lipid traits in the muscle and perirenal fat of growing rabbits fed mixed diets. Animals, 2: 55-67.

Radwan, S. S. (1978). Coupling of two dimensional thin layer chromatography with gas chromatography of the quantitative analysis of lipids classed and their constituent fatty acids. J. Chromatogr. Sci., 16: 538542.

Richmond, W. (1973). Preparation and properties of cholesterol oxidase from Nocardiasp and application to the enzymatic assay of total cholesterol in serum. Clin. Chem., 19: 1350-1356.

Rothwell, N. J. and M. J. Stock (1983). Diet-induced thermogenesis. In Mammalian Thermogenesis, ed. giradier, 1. \& stock, M. J., pp. 208-232. London: Chapman \& Hall.

Sabin, K., N. Sahin, M. Onderci, S. Yarahoglu and O. Kucuk (2001). Protective role of supplemental vitamin $\mathrm{E}$ on lipid peroxidation, vitamins $\mathrm{E}$ and $\mathrm{A}$ and some minerals concentrations of broilers reared under heat stress. Veterinarnimedicina Czech, 46: 140-144.

Sadq, S. M., D. O. M. Ramzi, H. J. Hamasalim and K. A. Ahmed (2016). Growth performance and digestibility in Karadi lambs receiving different levels of pomegranate peels. Open Journal of Animal Sciences, 6: 16-23.

Sahin, K. and O. Kucuk (2003). Heat stress and dietary vitamin supplementation of poultry diets. Nutr. Abstr. Rev. Ser. B Livest. Feeding 73, 41R-50R.

Salama, Maha, F. A. (2011). Studies on the possibility of producing n-3 enriched rabbit meat. M. Sc. Thesis, Fac. Agric. (Saba Basha), Alexandria University, Egypt.

Saleh, A., T. A. Ebeid and Y. Z. Eid (2013). The effect of dietary linseed oil and organic selenium on growth performance and muscle fatty acids in growing rabbits. Pak. Vet. J., 33(4): 450-454.

Simopoulos, A. P. (2000). Human requirement for n-3 polyunsaturated fatty acids. Poultry Science, 79: 961 970.

Singh, R. P., G. K. Jayaprakasha and K. K. Sakariah (2009). A process for the extraction of antioxidants from pomegranate peels. Indian Paten Applied. 12 pp.

SPSS (2001). Statistical Packages for the Social Sciences. Statistical software for windows version 11.0 Microsoft. SPSS ${ }^{\circledR}$, Chicago, IL, USA.

Trebušak, T., A. Levart, M. Voljč, U. Tomažin and T. Pirman (2011). The effect of linseed oil supplementation on performance, fatty acid composition and oxidative status of rabbits. Acta Argic. Slovenica, 98: 119-125.

Tzulker, R., I. Glazer, I. Bar-ilan, D. Holland, M. Aviram and R. Amir (2007). Antioxidant activity, polyphenol content and related compounds in different fruit juices and homogenates prepared from 29 different pomegranate accessions. Journal of Agriculture and Food Chemistry, 55: 9559-9570.

Vakili, R., A. A. Rashidi and S. Sobhanirad (2010). Effects of dietary fat, vitamin E and zinc supplementation on tibia breaking strength in female broilers under heat stress. African Journal of Agricultural Research, 5, 23: 3151-3156. 
Villalobos, O., O. Guillen and J. Garcia (2008). Effect of cage density on growth and carcass performance of fattening rabbits under tropical heat stress conditions. World Rabbit Science 16: 89-97.

Viuda-Martos, M., J. Fern'andez-L'opez, and J.A. P'erez-'Alvarez (2010). Pomegranate and its Many Functional Components as Related to Human Health: A Review. Comprehensive Reviews in Food Science and Food Safety. 9:635-654.

Wegmann, T. G. and O. Smithies (1966). A simple hemagglutination system requiring small amount of red cells and antibodies. Transfusion, 6: 67-73.

Yehuda, S., C.E. Leprohon-Greenweed, L.M. Dixon and D.V. Coscina (1986). Effects of dietary fat on pain threshold, thermoregulation and motor activity in rats. Pharmacol. Biochem. Behav., 24: 1775-1777.

Zeweil, H. S. , S. M. Zahran, M. H. Ahmed, Y., El- El-Gindy and W. G. M. Shaglouf (2016). Effects of allicin and lycopene on performance, carcass, hematological profile and antioxidant status of growing rabbits through summer season. Journal of the Advances in Agriculture Research,. 21,4: 622-637.

Zeweil.H. S., S. M. Zahran., Samar Elnagar., M. H. Ahmed., W. Dosoky and Yassmine El-Gindy (2012).Study of the effect of pomegranate peel as a natural antioxidant on the performance of New Zealand White rabbits during summer season. 3rd Mediterranean Poultry Summit and $6^{\text {th }}$ International Poultry Conference, 26 - 29 March 2012, Alexandria, Egypt.

Zsédely, E., T. Tóth, C. Eiben, G. Tobias, S. Godor, B. Vegi, G. Virág and J. Schmidt (2006). Influence of sunflower and linseed oil supplementation of rabbit feed. 2. Composition and fatty acids profile of the meat and liver of rabbits. In: 18. NyúltenyésztésiTudományos Nap, Kaposvár, 59-65.

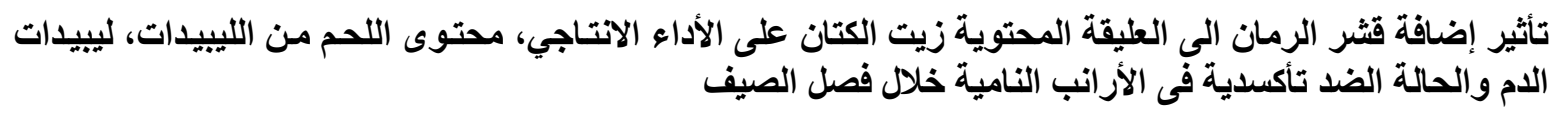

$$
\begin{aligned}
& \text { حسن صابر زويل ، محمد حسن أحمد ، سليمان محمد زهران ، ياسمين مؤمن الجندى ، ايوب السنوسي عبد القادر } \\
& \text { قسم الإنتاج الحيوانى والسمى ـ كلية الزراعة سابا باثا - جامعة الاسكندرية ـ الاسكندرية - مصر. }
\end{aligned}
$$

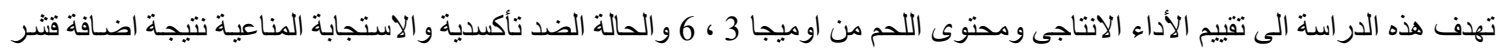

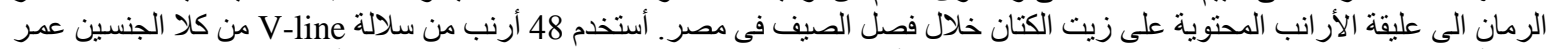

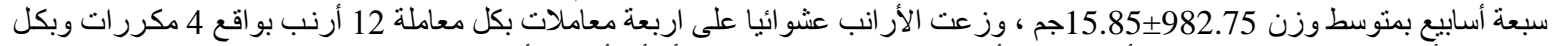

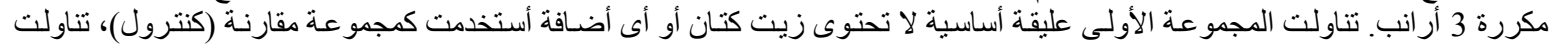

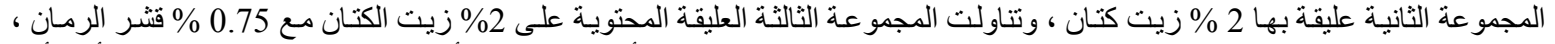

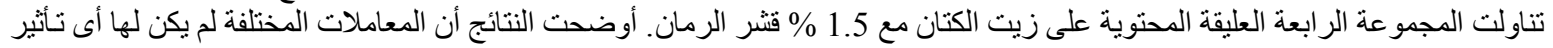

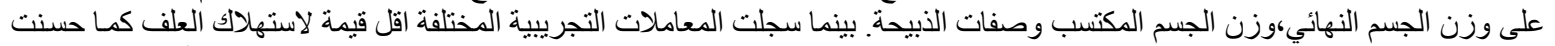

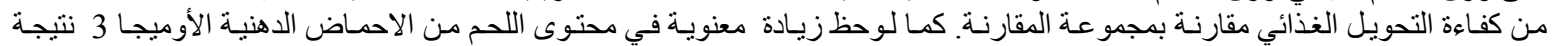

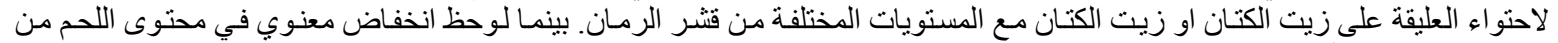

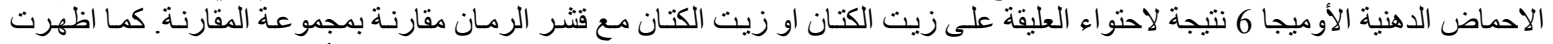

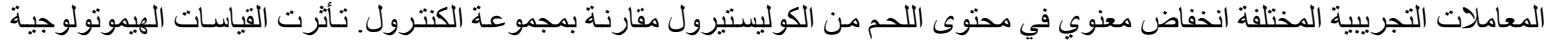

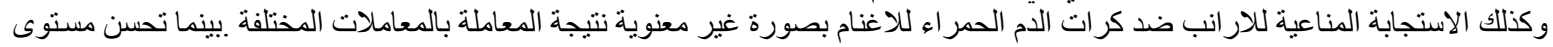

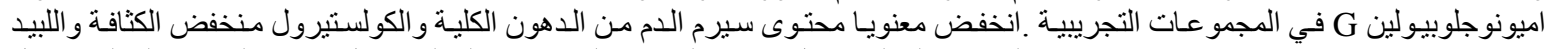

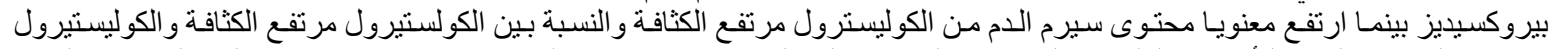

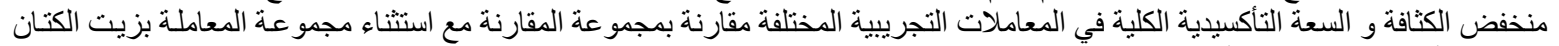

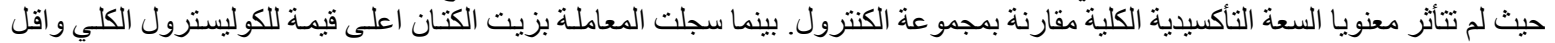

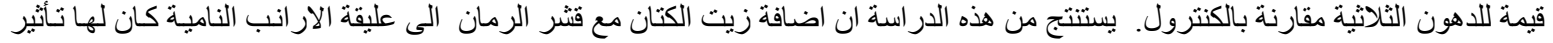

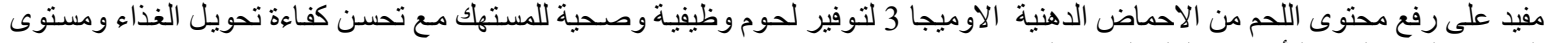

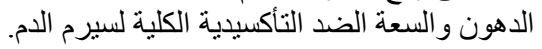

